\title{
Hippobosca longipennis - a potential intermediate host of a species of Acanthocheilonema in dogs in northern India
}

Puteri Azaziah Megat Abd Rani ${ }^{1,3^{*}}$, Glen T Coleman ${ }^{1}$, Peter J Irwin² and Rebecca J Traub ${ }^{1}$

\begin{abstract}
Background: Hippobosca longipennis (the 'dog louse fly') is a blood sucking ectoparasite found on wild carnivores such as cheetahs and lions and domesticated and feral dogs in Africa, the Middle East and Asia, including China. Known as an intermediate host for Acanthocheilonema dracunculoides and a transport host for Cheyletiella yasguri, it has also been suggested that $H$. longipennis may be a vector for other pathogens, including Acanthocheilonema sp.? nov., which was recently reported to infect up to $48 \%$ of dogs in northern India where this species of fly is known to commonly infest dogs. To test this hypothesis, hippoboscid flies feeding on dogs in Ladakh in northern India were collected and subjected to microscopic dissection.

Results: A total of 12 infective larvae were found in 10 out of 65 flies dissected; 9 from the head, 2 from the thorax and 1 from the abdomen. The larvae averaged 2, 900 ( \pm 60$) \mu \mathrm{m}$ in length and $34( \pm 5) \mu \mathrm{m}$ in width and possessed morphological features characteristic of the family Onchocercidae. Genetic analysis and comparison of the 18S, ITS-2, 125 and cox-1 genes confirmed the identity of the larvae as the Acanthocheilonema sp.? nov. reported in dogs in Ladakh.

Conclusion: This study provides evidence for a potential intermediate host-parasite relationship between $H$. longipennis and the canine Acanthocheilonema sp.? nov. in northern India.
\end{abstract}

\section{Background}

Hippoboscids are highly specialised larviparous ectoparasitic flies, spending all or most of their adult life within the fur or among feathers of their mammal and avian hosts [1]. The family Hippoboscidae is divided into three subfamilies; Lipopteninae, Ornithomyiinae and Hippoboscinae. This family represents one of the most important blood-sucking insect groups of birds and ruminants [2], however comparatively little attention has been paid to their role as an ectoparasite of dogs and their potential as an intermediate host for canine parasites.

Wild and domestic canids represent the preferred/primary hosts for Hippobosca longipennis [3]. The geographical distribution of $H$. longipennis includes arid and semi arid regions of southern Europe, Africa, the Middle

\footnotetext{
* Correspondence: puteri.megatabdrani@uqconnect.edu.au

'School of Veterinary Science, The University of Queensland, Gatton,

Queensland, Australia

Full list of author information is available at the end of the article
}

East and Asia, including China and India [4-6]. In 1970, $H$. longipennis was introduced into the United States after infested captive cheetahs were imported from east Africa [7] and the flies were subsequently detected on cheetahs at safari parks in Texas, Georgia and Oregon. Eradication efforts were successful and since then there is no evidence that this species has become established in the United State or elsewhere in the New World [6-8]. Hippobosca longipennis has been reported to alight on humans [5] and occasionally bite [3], but the extent of their ability to feed on humans is unknown. The fly has been reported infesting Indian dogs since 1966 and has been reported in Uttar Pradesh, Himachal Pradesh, Jammu and Kashmir, Punjab, Assam, West Bengal and the eastern zone of Maharashtra state $[3,5,9,10]$.

With the exception of Dirofilaria immitis and Dirofilaria repens, other species of canine filarial infections are generally asymptomatic, but microfilariae have been associated with skin hypersensitivity reactions $[11,12]$.
C Biomed Central

C 2011 Rani et al; licensee BioMed Central Ltd. This is an Open Access article distributed under the terms of the Creative Commons Attribution License (http://creativecommons.org/licenses/by/2.0), which permits unrestricted use, distribution, and reproduction in any medium, provided the original work is properly cited. 
Adult filarial nematodes of the genus Acanthocheilonema are usually found in the body cavities and/or subcutaneous tissues of their mammalian host. The public health significance of the genus Acanthocheilonema appears to be minimal, with only one case of an adult female Acanthocheilonema reconditum reported in the eye of a human, in Australia [13]. Fleas and lice are intermediate hosts for $A$. reconditum [14]. Ticks, lice $[15,16]$ and, in Algeria, H. longipennis, have all been proposed as intermediate hosts for Acanthocheilonema dracunculoides [17]. The development of larvae in these intermediate hosts occurs mostly in the fat-body cells and infective larvae migrate to the mouthparts to facilitate their transmission $[18,19]$.

Recently we reported the discovery of a canine filarial worm that was referred to erroneously as Acanthocheilonema ladakhii (currently nomen nudum), in 48\% of a dog population sampled in northern India [20]. To date very little is known about the clinical significance of this parasite except that its microfilariae may be confused with those of $D$. immitis, especially by minimally trained personnel [21], and that almost all the dogs in this region were heavily infested with $H$. longipennis [20].

The aim of this study was to report the occurrence of the newly reported Acanthocheilonema parasite in $H$. longipennis in dogs in northern India, using a combination of conventional and molecular diagnostic techniques. This species of Acanthocheilonema (currently nomen nudum) will be referred to as Acanthocheilonema sp.? nov. throughout this manuscript.

\section{Materials and methods}

\section{Study site and sampling}

Approximately 200 adult flies belonging to the genus Hippobosca (Figure 1) were manually removed from dogs presented to the Street Dog Sterilisation Programme in Ladakh, India, from June to September 2008. This collaborative program, involving the Ladakh Animal Care Society and Vets Beyond Borders, aims to stabilise the street dog population and helps to control rabies and other canine zoonoses. The flies were deposited into screw-cap tubes and immediately fixed in 70\% ethanol.

\section{Identification and dissection}

Flies were examined using a stereomicroscope and identified morphologically according to criteria specified by Bequaert [3]. The flies were then individually dissected; after discarding legs and wings, each specimen was divided into three body sections (head, thorax and abdomen). Flies were dissected in phosphate-buffered saline (PBS) using curved-bladed Vannas scissors (ProSciTech, Australia).

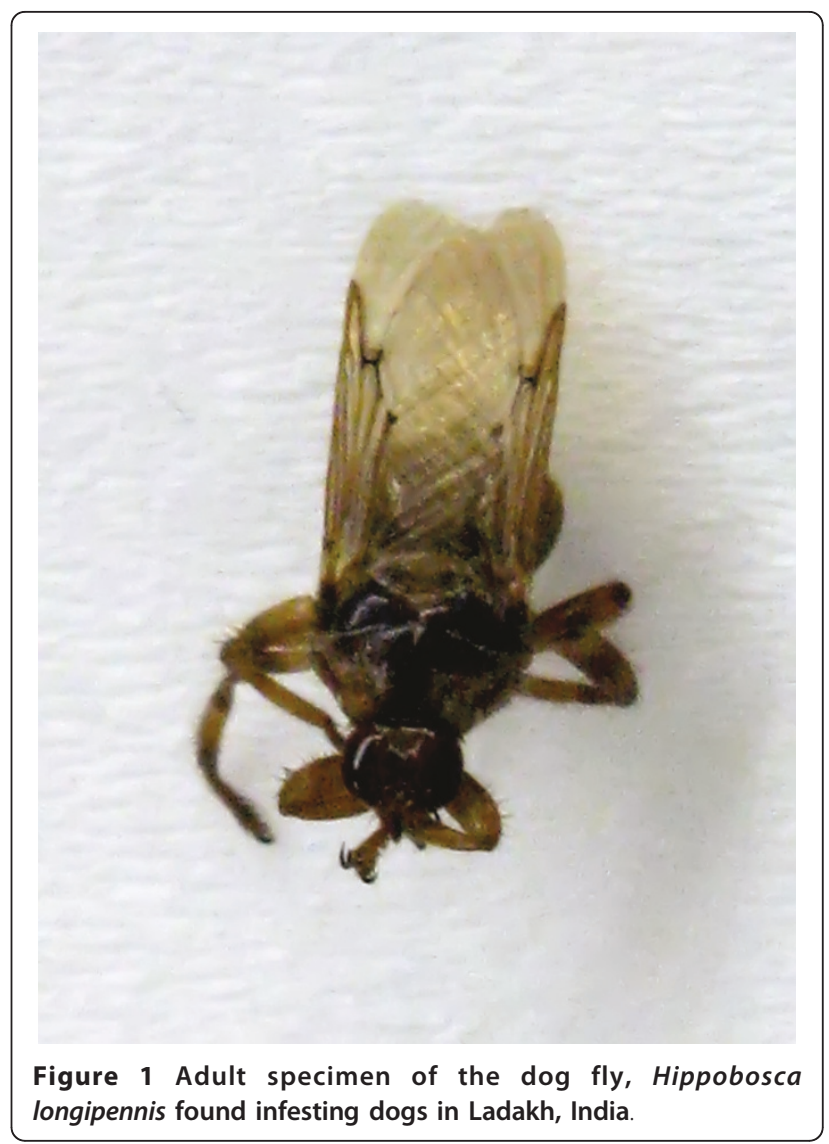

All isolated nematode larvae were examined microscopically at $\times 200$ and $\times 400$ magnification for morphological identification with reference to an atlas for infective larvae of filarial parasites [22]. The larvae were measured using a $\mathrm{BH}-2$ microscope (Olympus, Japan) with a calibrated eye micrometer and photographed using a DP12 digital microscope camera (Olympus, Japan).

\section{DNA Extraction, PCR assays and DNA sequencing}

DNA extraction was performed on collected larvae using a commercial kit (DNeasy Tissue Kit; Qiagen) and subjected to PCR for genus and species identification. A single DNA sample of canine blood positive for microfilariae of Acanthocheilonema sp.? nov. was randomly selected from the authors' previous study [20] and was genetically characterised at two additional mitochondrial genes for confirmation of species identification.

For genus-based identification of larvae, a forward primer, Mff18SF1 5' GGA TAA CTG TGG CAA TTC TAG 3' was designed by aligning the sequences of the near complete 18S rDNA of Brugia malayi [GenBank: AF036588], Wuchereria bancrofti [GenBank: AF227234], D. immitis [GenBank: AF036638] and Dipetalonema sp. [GenBank: DQ531723.1] using ClustalW (http://www. genome.jp/tools/clustalw/) and combined with reverse 
primer, PAFilariaR1 [20], to amplify a 700bp PCR product.

The PCR assay was carried out in a volume of $25 \mu \mathrm{l}$ containing $1 \times$ PCR buffer (Qiagen), $2.0 \mathrm{mM} \mathrm{MgCl}$, $200 \mu \mathrm{M}$ of each dNTP, $0.5 \mu \mathrm{M}$ of each of the forward and reverse primers, $0.5 \mathrm{U}$ of Taq DNA polymerase (Qiagen) and $1 \mu \mathrm{l}$ of extracted DNA (concentration for each DNA samples ranged from 1.5 to $1.7 \mathrm{ng} / \mu \mathrm{L}$ ). The PCR conditions were as follows: an initial activation step at $94^{\circ} \mathrm{C}$ for 2 min was followed by 35 cycles of amplification $\left(94^{\circ} \mathrm{C}\right.$ for $30 \mathrm{~s}, 60^{\circ} \mathrm{C}$ for $30 \mathrm{~s}$ and $72^{\circ} \mathrm{C}$ for $\left.30 \mathrm{~s}\right)$ followed by a final extension step of $72^{\circ} \mathrm{C}$ for 7 minutes.

The larvae were subjected to PCR to amplify the internal transcribed spacer-2 (ITS-2) region using PCR assays and conditions previously described by Rishniw [21]. Larvae and microfilariae were also subjected to PCR amplification of the mitochondrial $12 \mathrm{~S}$ rDNA and cytochrome oxidase - $1(\operatorname{cox}-1)$ genes. Amplifications and sequences of $12 \mathrm{~S}$ rDNA were generated using a primer pair 12SF and 12SR [23]. PCR was performed in a $25 \mu \mathrm{l}$ final volume under the following conditions: $1 \times$ buffer A with $1.5 \mathrm{mM} \mathrm{MgCl}_{2}$ (KAPA2G $\left.{ }^{\mathrm{TM}}\right), 0.2 \mathrm{mM}$ of each dNTP, $1 \mu \mathrm{M}$ of each primer, and $0.75 \mathrm{U}$ of KAPA2GTM Robust HotStart DNA Polymerase (KAPA2G ${ }^{\mathrm{TM}}$ ). The thermal profile used was: $95^{\circ} \mathrm{C} 30 \mathrm{~s}$ followed by $95^{\circ} \mathrm{C} 30$ s, $50^{\circ} \mathrm{C} 15 \mathrm{~s}$, and $72^{\circ} \mathrm{C} 30 \mathrm{~s}$ for 35 cycles and $72^{\circ} \mathrm{C}$ for $60 \mathrm{~s}$. The $c o x-1$ sequences were generated using the primer pair COIintF and COIintR using conditions described by Casiraghi and colleagues [24].

PCR products were purified using Qiagen spin columns (Qiagen) and sequenced using an ABI 3130xl Genetic Analyser (Applied Biosystems) with Big Dye 3.0 chemistry. The sequences were read, edited and assembled using Finch TV (Geospiza Inc.) and BioEdit Sequence Alignment Editor version 7.0.5.3.

Neighbor joining analyses were conducted with Tamura-Nei parameter distance estimates and trees constructed using Mega 4.1 software. Bootstrap analyses were conducted using 1000 replicates.

\section{Results}

More than 200 flies were collected from a total of 101 dogs. From these a total of 65 flies were selected randomly and identified morphologically as $H$. longipennis. Twelve nematode larvae were found in 10 out of 65 flies dissected; 9 from the head (Figure 2), 2 from the thorax and 1 from the abdomen. Two flies were found with mites attached to the setae of their legs and these mites were identified as Cheyletiella yasguri (Figure 3) according to Domrow [25].

The larvae were relatively large, with a mean total body length of 2,900 $( \pm 60) \mu \mathrm{m}$ and width of $34( \pm 5)$ $\mu \mathrm{m}$. Apart from being larger, all extracted larvae closely resembled other infective larvae of the family

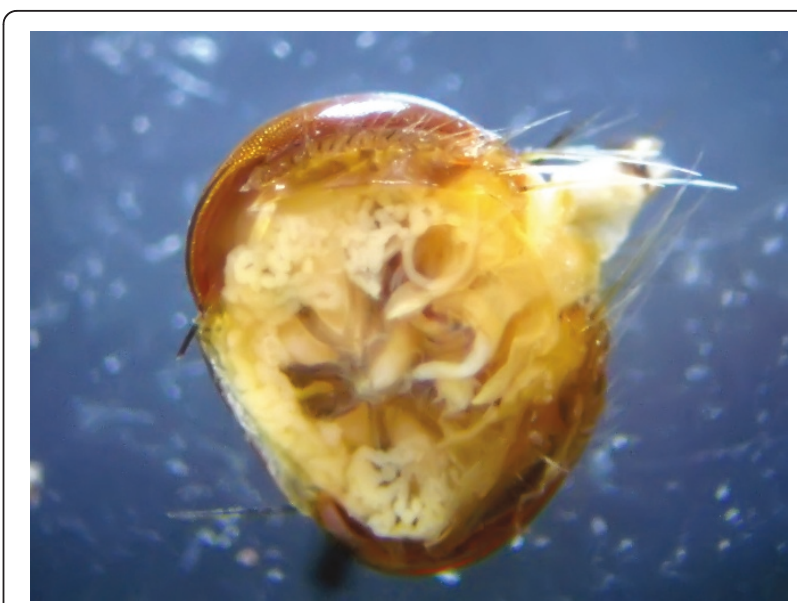

Figure 2 An infective larva of Acanthocheilonema sp.? nov. in situ within the head of a Hippobosca longipennis fly.

Onchocercidae (species of the genera Dirofilaria, Brugia, Cerchopithifilaria and Acanthocheilonema), with a characteristic subterminal lateral caudal appendage (Figure 4 ), regardless of the location within the flies.

Nine of the 11 larvae were subjected to PCR amplification at the 18S, ITS- 2 genes, $12 \mathrm{~S}$ and cox-1 genes. DNA sequences of all larvae displayed 100\% homology to the Acanthocheilonema sp.? nov. at all four genetic loci. The un-rooted phenogram using neighbour joining analyses of the ITS-2, 12 S and cox-1 sequences showed $100 \%$ bootstrap placement for all nine larvae sequences with Acanthocheilonema sp.? nov. into a distinct group from $A$. reconditum as well as $A$. vitae (Figure $5,6,7$ ).

\section{Discussion}

This study represents the first report of the dog louse fly, $H$. longipennis, acting as a potential intermediate

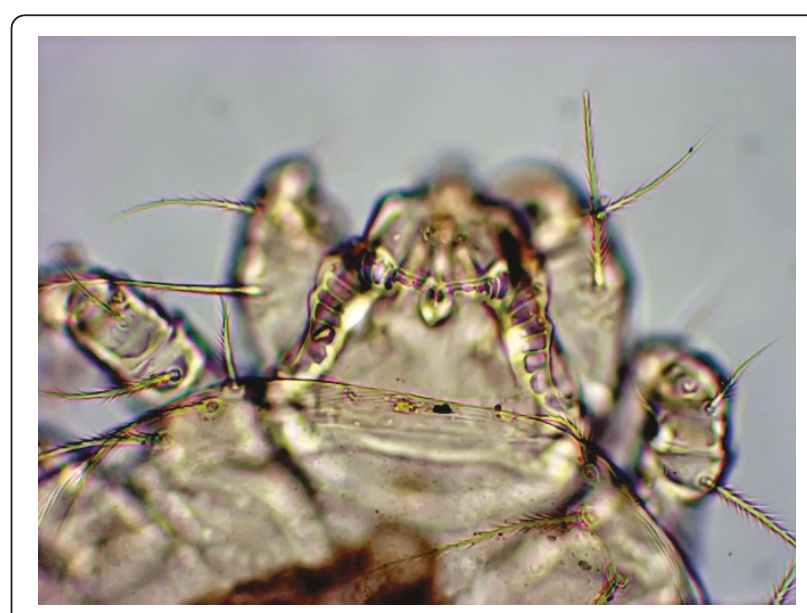

Figure 3 The heart-shaped of the dorsal solenidion on genu I of the first leg confirms the mite species as Cheyletiella yasguri. 


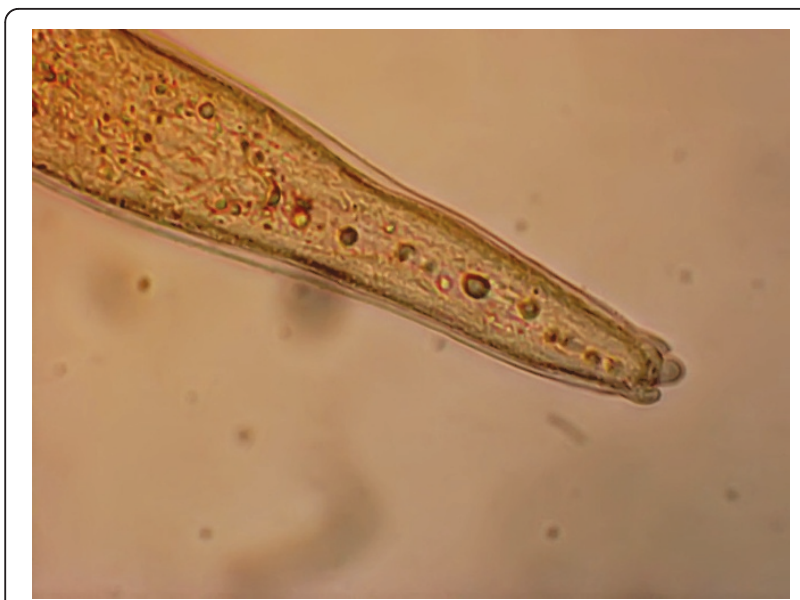

Figure 4 The subterminal lateral caudal appendage of the infective larvae of Acanthocheilonema sp.? nov., a characteristic feature of the infective larvae from family Onchocercidae.

host of the recently identified species of canine filarial nematode Acanthocheilonema sp.? nov.. Both conventional parasitological and molecular methods provide evidence of biological involvement between $H$. longipennis and this parasite in northern India. Despite careful examination of different anatomical regions of the flies during dissection, only infective larvae were observed; this is similar to the findings of Nelson [17] who also failed to find other developmental stages of larvae of $A$. dracunculoides except for a single second stage larva found in the abdominal cavity. Nelson suggested that the absence of other developmental stages may have been due to the prolonged feeding interval of the fly, which could allow larvae to become fully infective before re-feeding on the host a few days later. Hafez and Hilali [26] however demonstrated that the fly could only withstand starvation for 12 to 36 hours before dying and that feeding occurs more regularly than this. It is reported that the developmental period from L1 to infective larvae for $A$. reconditum in fleas and $A$. dracunculoides in ticks is approximately seven days and thirteen days, respectively [16,27]. The development of Acanthocheilonema sp.? nov. within its hippoboscid host therefore requires further investigation. Despite the fact that we have demonstrated a potential intermediate host-parasite relationship between $H$. longipennis and Acanthocheilonema sp.? nov., determination of the vector competence for any blood-feeding arthropod should be based on the demonstration of its capability of transmitting the parasite to a receptive host during blood feeding using experimental trials [15,27], and this remains to be performed.

The precise identification of this nematode remains unclear. A proper morphological comparison of the third-stage larvae, microfilaria and recovery and comparison of adult worms with those of the other filarial nematodes of dogs in addition to the molecular phylogenetics would be required in order to comply with the establishment criteria listed in Article 7 to 11 of the Code of Zoological Nomenclature, which would allow official classification of this Acanthocheiloma sp. nov.? found in dogs.

Species of Hippobosca do not normally travel long distances but they are strong fliers and will actively fly between hosts within a group [28]. When on the host,

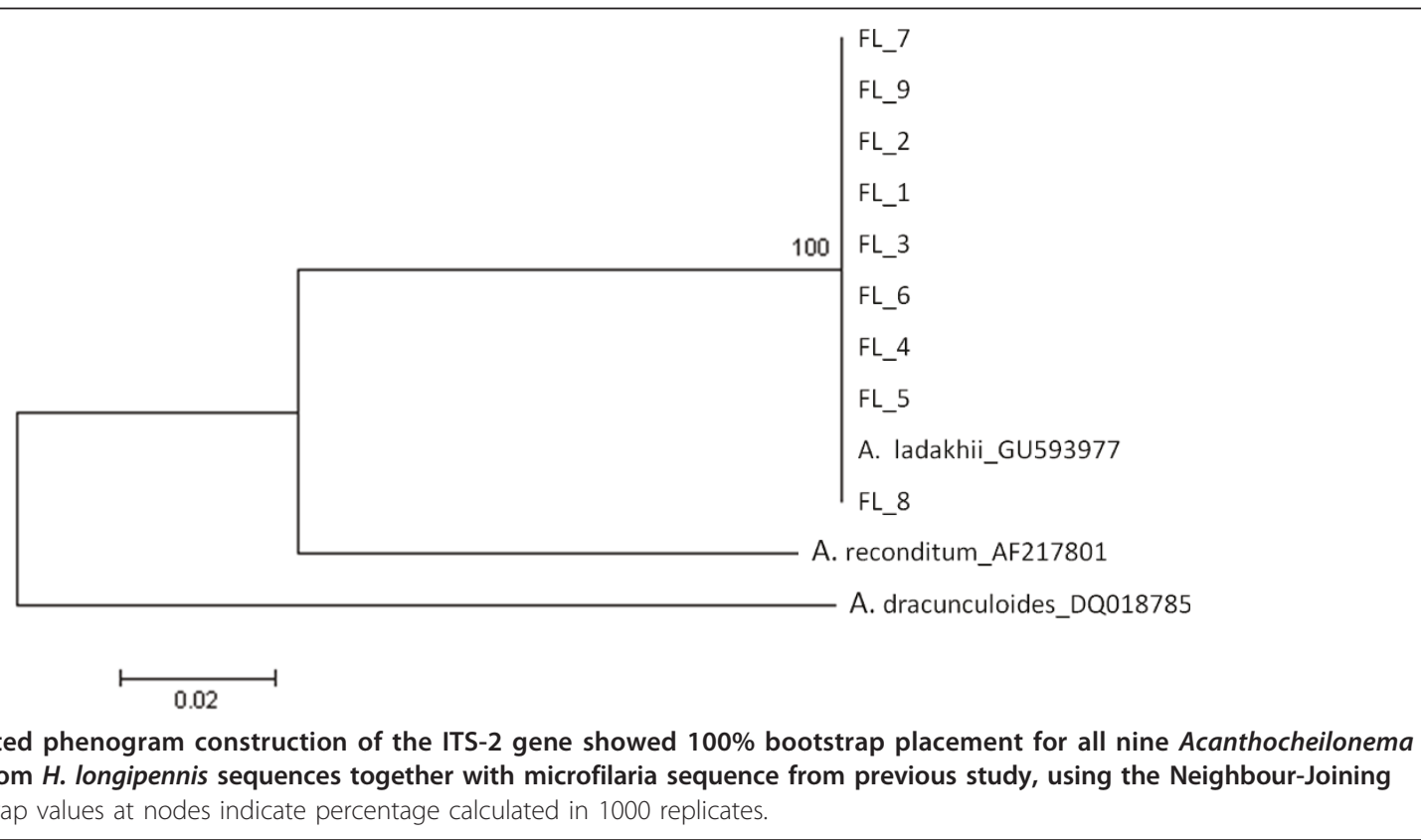




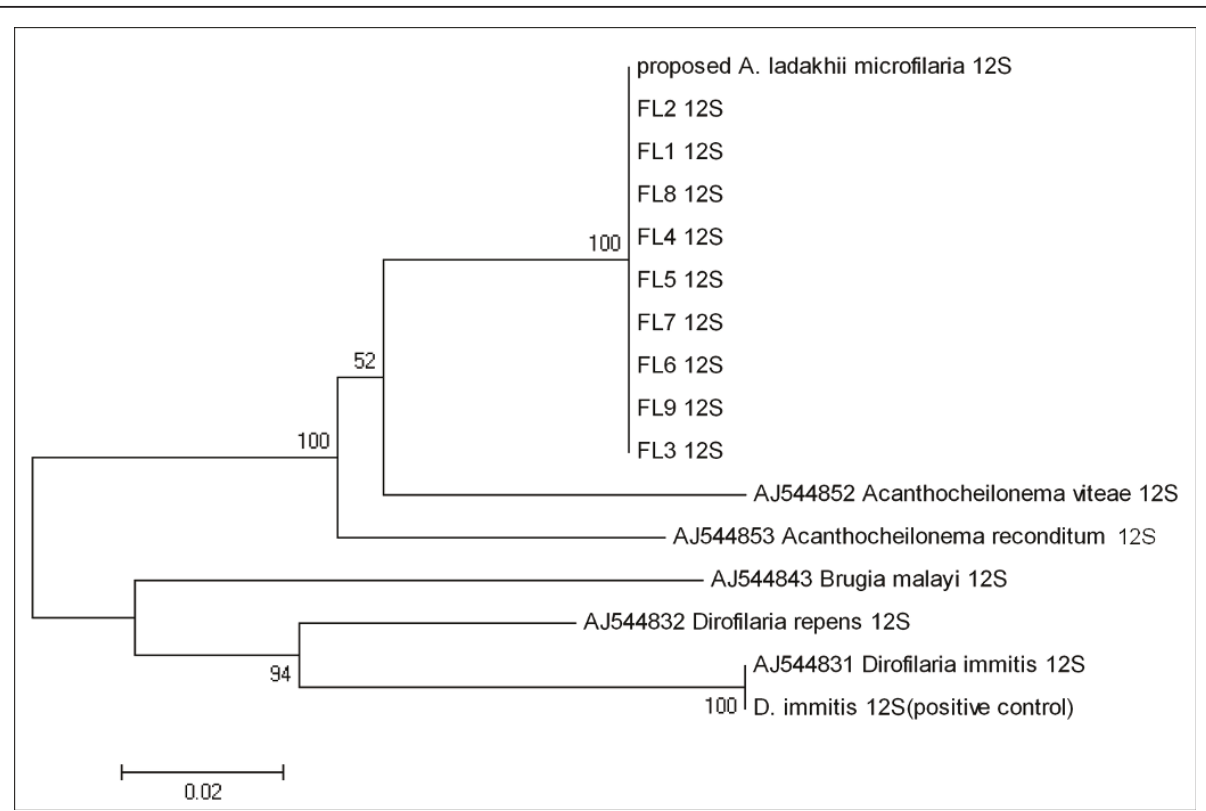

Figure 6 Un-rooted phenogram construction of the $12 \mathrm{~S}$ gene using the Neighbour-Joining algorithm. Bootstrap values at nodes indicate percentage calculated in 1000 replicates. The phenogram showed 100\% bootstrap placement for all nine Acanthocheilonema larvae isolated from $\mathrm{H}$. longipennis sequences together with microfilaria sequence from previous study and forming a sister group with other species of Acanthocheilonema,

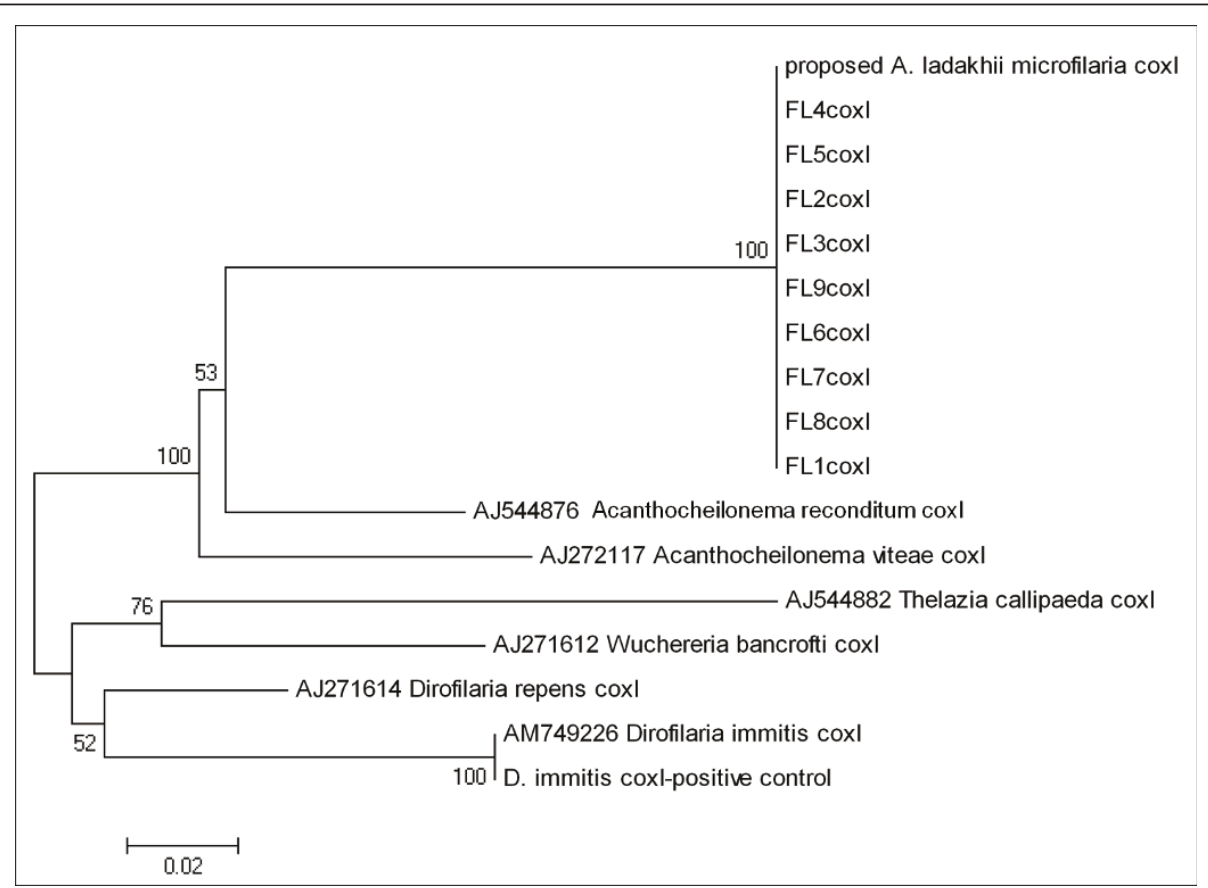

Figure 7 Un-rooted phenogram construction of the cox-1 gene showed 100\% bootstrap placement for all nine Acanthocheilonema larvae isolated from $\mathrm{H}$. longipennis sequences together with microfilaria sequence from previous study and forming a sister group with other species of Acanthocheilonema, using the Neighbour-Joining algorithm. Bootstrap values at nodes indicate percentage calculated in 1000 replicates. 
H. longipennis moves swiftly between hairs and is very difficult to catch (authors' personal observation). It is known that on average the female leaves the host for larviposition (on the soil, in crevices or in cracks of tree barks) about 8 times throughout her lifetime, on each occasion she returns to the host to feed and start another larval maturation cycle [26]. Hafez and Hilali [26] stated that the amount of complete blood meal ingested by $H$. longipennis varies from 1.5 to $4.5 \mathrm{mg}$ with a feeding duration of 3 to 13 minutes and meals are taken at least every 6 hours. This information highlights the significance of this fly as important blood sucking ectoparasite, hence increasing the opportunity for it to be an effective disseminator of blood parasites among dogs.

The subfamilies Lipopteninae, and Ornithomyiinae are known biological vectors for Trypanosoma and Haemoproteus of birds, sheep and goat [2]. The subfamily Hippoboscinae has been documented only as a vector for $A$. dracunculoides in dogs [17]. More recently, over 70\% of Hippobosca equina were positive for Bartonella DNA [29], but further investigation is needed to clarify biological or mechanical involvement of the fly as a vector for this pathogen. To the authors' knowledge, there are no other reports exploring the role of the genus Hippobosca as a vector/intermediate host for any other pathogen. Indeed, it is surprising how little information is known about the capability of the subfamily Hippoboscinae as vectors of pathogens. Further investigations are crucial to reduce this knowledge gap.

Despite being commonly encountered in semi-arid regions of Africa and Asia, there is no peer-reviewed information available on the efficacy of ectoparasitic drugs against $H$. longipennis on dogs. Staff at several zoos in United States applied methoxychlor, malathion and carbaryl-sulfur dust formulations to the animals and their surroundings to control and eradicate $H$. longipennis infestations $[7,8]$. In addition to its role as an intermediate host for canine filariae, our findings have also confirmed earlier reports that $C$. yasguri mites are phoretic on $H$. longipennis [30,31] and that the fly may play an important role in mechanically disseminating this mite among dogs. The fly's potential to cause heavy infections of dogs with accompanying anaemia and/or skin lesions, signals a need for further studies to determine the efficacy of currently available insecticides against $H$. longipennis.

With respect to the public health significance of this epifaunistic ectoparasite, it is known that humans are occasionally bitten by flies from the family Hippoboscidae [3], but it is of note that the authors did not receive any bites from $H$. longipennis during the collection process. Apart from mechanical irritation and injury, the fly may also facilitate the zoonotic transmission of $C$. yasguri [32]. It has also been hypothesised that $H$. longipennis may act as a mechanical vector for Leishmania spp. in areas where the parasite is endemic in dogs [8]. Furthermore, $H$. equina (forest fly) and Lipoptena cervi (deer ked), other blood-sucking species belonging to the family Hippoboscidae, have been reported feeding on [33] and causing anaphylactic reactions in humans in Finland [34] and Hungary [35] and this may also be a possibility with $H$. longipennis. In summary, to date, this fly appears to have minimal public health significance, but further investigation is needed to verify this.

\section{Conclusion}

This study confirmed biological involvement of $H$. longipennis for Acanthocheilonema sp.? nov. in northern India and its role as an intermediate host is proposed. Further investigations are essential to prove whether this fly is a competent vector for Acanthocheilonema sp.? nov.. Furthermore, future research needs to be conducted to investigate whether $H$. longipennis is capable of propagating and transmitting other vector-borne and zoonotic pathogens.

\section{Acknowledgements}

Financial support for this study was provided by Bayer Animal Health. We gratefully thank our collaborator Vets Beyond Borders for their help with the fieldwork. Special thanks to Lynn Knott for her help with identification and pictures. PhD scholarship support for Puteri Azaziah Megat Abd Rani is provided by The Ministry of Higher Education, Malaysia.

Publication of this thematic series has been sponsored by Bayer Animal Health $\mathrm{GmbH}$.

\section{Author details}

'School of Veterinary Science, The University of Queensland, Gatton, Queensland, Australia. ${ }^{2}$ School of Veterinary and Biomedical Science, Murdoch University, Western Australia, Australia. ${ }^{3}$ Faculty of Veterinary Medicine, Universiti Putra Malaysia, Malaysia.

\section{Authors' contributions}

PAMAR was involved in all phases of the study, including sampling and data collection, laboratory work, data analysis, intellectual interpretation, and writing the manuscript.

RJT designed the study project, supervised the study, and was involved in sampling, field data collection, intellectual interpretation and critical revision of the manuscript for publication.

PJI and GTC supervised the study and were involved in intellectual interpretation and critical revision of the manuscript for publication. All authors read and approved the final manuscript.

\section{Competing interests}

The authors declare that they have no competing interests.

Received: 11 February 2011 Accepted: 22 July 2011

Published: 22 July 2011

\section{References}

1. Maa TC: Notes on the Hippoboscidae (Diptera), I. Pac Insects 1962, 4:583-614.

2. Baker JR: A review of the role played by the Hippoboscidae (Diptera) as vectors of endoparasites. J Parasitol 1967, 53:412-418.

3. Bequaert J: Notes on Hippoboscidae 2. The subfamily Hippoboscinae. Psyche (Stuttg) 1930, XXXVII:303-326. 
4. Bequaert J: Notes on Hippoboscidae 13. A second revision of the Hippoboscinae. Psyche (Stuttg) 1940, XLVII:70-90.

5. Bhat HR, Kulkarni SM: A survey of haematophagus arthropods in western Himalayas, Sikkim and hill districts of West Bengal: Pupipara (Diptera) (families: Hippoboscidae, Nycteribiidae and Streblidae). Ind J Med Res 1974, 62:1121-1133.

6. Mullen GR, Durden LA: Medical and veterinary entomology. 2 edition. Boston: Academic; 2009

7. Keh B, Hawthorne RM: The introduction and eradication of an exotic ectoparasitic fly, Hippobosca longipennis (Diptera: Hippoboscidae), in California. J Zoo Ani Med 1977, 8:19-24.

8. Hippobosca longipennis. [http://www.cfsph.iastate.edu/Factsheets/pdfs/ hippobosca_longipennis.pdf].

9. Vanak AT, Belsare AV, Gompper ME: Survey of disease prevalence in freeranging domestic dogs and possible spill-over risk for wildlife - A case study from the Great Indian Bustard Sanctuary, Maharastra - India. The Rufford Small Grants Foundation, UK; 2007, 1-13.

10. Sharma SK, Soodan JS, Bal MS, Khajuria JK, Upadhyay SR: Parasitic dermatitis in canines of Jammu region. J Vet Parasitol 2009, 23.

11. Grieve RB, Lok JB, Glickman LT: Epidemiology of canine heartworm infection. Epidemiol Rev 1983, 5:220-246.

12. Tarello W: Dermatitis associated with Dirofilaria repens microfilariae in three dogs in Saudi Arabia. J Small Anim Pract 2003, 44:132-134.

13. Huynh T, Thean J, Maini R: Dipetalonema reconditum in the human eye. $\mathrm{Br}$ J Ophthalmol 2001, 85:1391.

14. Nelson GS: Dipetalonema reconditum (Grassi, 1889) from the dog with a note on its development in the flea, Ctenocephalides felis and the louse, Heterodoxus spiniger. J Helminthol 1962, 36:297-308.

15. Olmeda-García AS, Rodríguez-Rodríguez JA, Rojo-Vázquez FA: Experimental transmission of Dipetalonema dracunculoides (Cobbold 1870) by Rhipicephalus sanguineus (Latreille 1806). Vet Parasitol 1993, 47:339-342.

16. Olmeda-García AS, Rodríguez-Rodríguez JA: Stage-specific development of a filarial nematode (Dipetalonema dracunculoides) in vector ticks. J Helminthol 1994, 68:231-235.

17. Nelson GS: Dipetalonema drancunculoides (Cobbold, 1870), from the dog in Kenya: wth a note on its development in the louse-fly, Hippobosca longipennis. J Helminthol 1963, 37:235-240.

18. Anderson R: Nematode parasites of vertebrates. Their development and transmssion. CABI Publishing, New York 2000, 650.

19. Bain O, Babayan S: Behaviour of filariae: morphological and anatomical signatures of their life style within the arthropod and vertebrate hosts. Fil J 2003, 2:16.

20. Megat Abd Rani PA, Irwin P, Gatne M, Coleman G, Mclnnes L, Traub R: A survey of canine filarial diseases of veterinary and public health significance in India. Parasit Vectors 2010, 3:30.

21. Rishniw M, Barr SC, Simpson KW, Frongillo MF, Franz M, Dominguez Alpizar JL: Discrimination between six species of canine microfilariae by a single polymerase chain reaction. Vet Parasitol 2006, 135:303-314.

22. Bain O, Chabaud A: Atlas des larves infestantes de Filaires. Trop Med Parasit 1986, 37:301-340.

23. Casiraghi M, Bain O, Guerrero R, Martin C, Pocacqua V, Gardner SL, Franceschi A, Bandi C: Mapping the presence of Wolbachia pipientis on the phylogeny of filarial nematodes: evidence for symbiont loss during evolution. Int J Parasitol 2004, 34:191-203.

24. Casiraghi M, Anderson TJC, Bandi C, Bazzocchi C, Genchi C: A phylogenetic analysis of filarial nematodes: comparison with the phylogeny of Wolbachia endosymbionts. Parasitology 2001, 122:93-103.

25. Domrow R: Acari Prostigmata (excluding Trombiculidae) parasitic on Australia vertebrates: an annoted checklist, keys and bibliography. Invert Taxon 1991, 4:1283-1376

26. Hafez M, Hilali M: Biology of Hippobosca longipennis (Fabricus, 1805) in Egypt (Dipteria: Hippoboscidae). Vet Parasitol 1978, 4:275-288.

27. Farnell DR, Faulkner DR: Prepatent period of Dipetalonema reconditum in experimentally-infected dogs. J Parasitol 1978, 64:565-567.

28. Walker A: The arthropods of humans and domestic animals: a guide to a preliminary identification London: Chapman and Hall; 1994.

29. Halos L, Jamal T, Maillard R, Girard B, Guillot J, Chomel B, VayssierTaussat M, Boulouis H-J: Role of Hippoboscidae flies as potential vectors of Bartonella spp. infecting wild and domestic ruminants. Appl Environ Microbiol 2004, 70:6302-6305.
30. Vercammen-Grandjean PH, Rak H: Cheyletiella yasguri Smiley, 1965, un parasite de Canides aux EtatsUnis et hyperparasite d'Hippoboscide en Iran (Acarina: Cheyletidae). Ann Parasit Hum Comp 1968, 43:405-412.

31. Rak H: Ectoparasites of dogs and cats in Iran. Entomologist's Monthly Magazine 1972, 108:189.

32. Wagner R, Stallmeister N: Cheyletiella dermatitis in humans, dogs and cats. $\mathrm{Br} J$ Dermatol 2000, 143:1110-1112.

33. Rantanen $T$, Reunala $T$, Vuojolahti PWH: Persistant pruritic papules from deer ked bites. Acta Derm Venereol 1982, 62:307-311.

34. Laukkanen A, Ruoppi P, Mäkinen-Kiljunen S: Deer ked-induced occupational allergic rhinoconjunctivitis. Ann Allergy Asthma Immunol 2005, 94:604-608.

35. Decastello A, Farkas R: Anaphylactic reaction following forest fly (Hippobosca equina) bite: A human case. Clin Exp Med 2010, 4:193-198.

\section{doi:10.1186/1756-3305-4-143}

Cite this article as: Rani et al:: Hippobosca longipennis - a potential intermediate host of a species of Acanthocheilonema in dogs in northern India. Parasites \& Vectors 2011 4:143.

\section{Submit your next manuscript to BioMed Central and take full advantage of:}

- Convenient online submission

- Thorough peer review

- No space constraints or color figure charges

- Immediate publication on acceptance

- Inclusion in PubMed, CAS, Scopus and Google Scholar

- Research which is freely available for redistribution

Submit your manuscript at www.biomedcentral.com/submit
C Biomed Central 